DOI: https://doi.org/10.24144/2409-6857.2018.2(52).49-52

УДК 338.2

Ігнатко M.I.

\title{
ОСОБЛИВОСТІ ІННОВАЦІЙНОЇ ДІЯЛЬНОСТІ В АГРОПРОМИСЛОВОМУ ВИРОБНИЦТВІ УКРАЇНИ
}

\begin{abstract}
Стаття присвячена дослідженню особливостей інновачійної діяльності в агропромисловому виробнищтві Украӥни. Розкрито специфіку впровадження інновацій в аграрному секторі економіки. Проведено моніторинг стану АПК України. Розкрито значення поняття "агроінновачія». Наведено чинники, які негативно впливають на розвиток агропромислового виробництва Украӥни. Проаналізовано способи активізації інноваційного розвитку в аграрному секторі економіки. Запропоновано напрямки інноваційного розвитку агропромислового виробництва Украӥни.
\end{abstract}

Ключові слова: інновачія, інновачійні прочеси, інноваційна діяльність, агроінновація, екоінновація, стимулювання агропромислового виробництва, інноваџійний розвиток.

Постановка проблеми. Агропромислове виробництво України є складовою національного господарства та виступає єдиною цілісною виробничо-економічною системою, що об'єднує низку сільськогосподарських, промислових, науково-виробничих i навчальних галузей, спрямованих на одержання, транспортування, зберігання, переробку та реалізацію сільськогосподарської продукції. За своїм складом та структурою він відрізняється від інших міжгалузевих комплексів i визначає соціально-економічний розвиток країни, рівень життя населення, продовольчу безпеку та забезпечення сільськогосподарською промисловості сировиною. Агропромислове виробництво відіграє велику роль у розвитку економіки України, адже займає значну частку в товарному експорті країни, демонструє зростаючі тенденції діяльності. Проте, сільськогосподарська продукція характеризується низьким рівнем конкурентоспроможності на європейському ринку. Ключовою проблемою виступає інноваційний розвиток агропромислового виробництва, що дозволяє змінити характер виробничої діяльності, перейти до нової організаційно-технологічної структури аграрного виробництва конкурентоспроможність вітчизняної продукції на ринках збуту.

Аналіз останніх досліджень і публікацій. У літературних джерелах зустрічається багато наукових праць, присвячених аналізу проблем інноваційного розвитку агропромислового виробництва України. Дану тематику досліджували

\footnotetext{
(C) Ігнатко Марія Іванівна, аспірант кафедри економіки і підприємництва ДВНЗ "Ужгородський національний університет", м. Ужгород, тел. +380959249929, e-mail: mariiahalas@ gmail.com
}

зарубіжні та вітчизняні науковці: I. Шумпетер, С.Валдайцев, О.Длугопольський, П. Друкер, М. Кизим, Р. Купер, В. Пригожин, Б. Санто, Р.Фатхутдінов, Д.Черваньов, Н. Левченко, Г.Павлова, О. Дацій, М. Зубець, О. Гончаренко, С.Іванюта, А. Шумський. У працях зазначених авторів розкрито економічні аспекти управління інноваціями в аграрному виробництві. Незважаючи на велику кількість публікацій, багато питань залишаються відкритими, що вимагає подальших наукових пошуків та обгрунтованих пропозицій стосовно особливостей інноваційної діяльності в агропромисловому виробництві.

Формулювання цілей статті. Головною метою цієї роботи $є$ вивчення особливостей інноваційної діяльності в агропромисловому виробництві України, визначення підходів для забезпечення його ефективного функціонування в сучасних економічних умовах.

Опис основного матеріалу дослідження. Україна $є$ одним із провідних виробників сільськогосподарської продукції в світі, що дозволяє забезпечити не лише потреби внутрішнього ринку, а й успішно експортувати продовольство та сільськогосподарську сировину. Частка експорту продукції аграрного сектору у загальному експорті країни станом на січень-липень 2018 року складає 36,9\%. До десятки країн, до яких найбільше експортується українська сільськогосподарська продукція, увійшли Індія $(12,1 \%)$, Сгипет $(6,4 \%)$, Китай (6,2\%), Нідерланди (5,9\%), Іспанія $(5,1 \%)$, Туреччина $(5,0 \%)$, Італія $(4,9 \%)$, Іран $(3,8 \%)$, Польща (3,6\%), Білорусь (3,5\%).

Варто зазначити, що у 13 областях відбулося збільшення продукції сільського господарства у січні-липні 2018 року у порівнянні з аналогічним періодом 2017 року, серед яких можна виділити Тернопільську (10,7\%), Житомирську (9,7\%), 
Сумську $(8,9 \%), \quad$ Волинську, Рівненську, Львівську (7,8\%) [1].

На сьогоднішній час українські підприємства агропромислового виробництва, які активно застосовують інновації, ні в чому не поступаються іноземним конкурентам, а інколи їх i перевершують. Тобто, в Україні є приклади успішного освоєння інновацій підприємствами АПК, але таких - абсолютна меншість. Більшість виробників сільськогосподарської продукції демонструють низький рівень продуктивності праці, незадовільне фінансове становище. У такому випадку величезного значення набуває саме поширення інновацій.

На думку Павлової Г.С., це пов'язано з тим, що:

- певною мірою зросла потреба товаровиробників аграрного сектора в інноваціях i сприйнятливість до передових технологій;

- створено нові підприємства, що зумовлено приходом у галузь нових власників та інвесторів;

- модернізовані через низький рівень ефективності деякі господарства, які відчувають потребу в передових технологіях;

- посилюється державна підтримка аграрного сектора економіки країни;

- $є$ значна кількість учасників, зацікавлених у створенні та просуванні, освоєнні інновацій в аграрному секторі [4, с. 132-133].

Інновації в агропромисловому виробництві $€$ реалізацією в господарській практиці результатів досліджень і розробок у вигляді нових сортів рослин, порід і видів тварин і кросів птаха, нових або поліпшених продуктів харчування, матеріалів, нових технологій в рослинництві, тваринництві і переробній промисловості, нових добрив і засобів захисту рослин і тварин, нових методів профілактики і лікування тварин і птаха, нових форм організації i управління, нових підходів до соціальних послуг, що дозволяють підвищити ефективність виробництва.

3 точки зору об'єктів інновацій, якими виступають елементи економічних систем, що беруть участь у виробничих процесах, інновації в агропромисловому виробництві - це інновації, що зачіпають безпосередньо процеси, учасниками яких є люди, машини i устаткування, а також елементи біосистеми, існування яких в природному середовищі неможливе або можливе тільки 3 втратою базових функціональних характеристик. Якщо врахувати всі внутрішні і зовнішні взаємозв'язки і взаємодії в агропромисловому виробництві, то за цільовою спрямованістю агроінновації можна розподілити на такі групи:

1. Інновації, спрямовані на вдосконалення об'єктів, що взаємодіють в процесі виробництва продукції: інновації, спрямовані на вдосконалення об'єкту «людина»; інновації, спрямовані на вдосконалення середової компоненти; інновації, спрямовані на вдосконалення системи механізмів, які використовуються в аграрній сфері, наприклад, підвищення надійності вузлів i агрегатів, підвищення економічності і ККД механізмів.

2. Інновації, спрямовані на вдосконалення взаємодій усередині агровиробничої системи: інновації, спрямовані на вдосконалення взаємодії людини i середового компонента; інновації, спрямовані на вдосконалення взаємодії між людиною i машиною, наприклад, створення ергономічних i інтуїтивно зрозумілих інтерфейсів; інновації, спрямовані на вдосконалення взаємодії між механізмами і середовою компонентою, наприклад, розробка тракторів зі зниженим тиском на грунт, що забезпечує оптимальніші режими вологості для кореневої системи рослин; інновації, спрямовані на вдосконалення взаємодії людини і продукту.

3. Інновації, спрямовані на вдосконалення взаємодії із зовнішнім середовищем функціонування агробізнесу: інновації, спрямовані на вдосконалення взаємодії між людиною i довкіллям, наприклад, прийняття державних програм підтримки бізнесу, що забезпечують, вибір і реалізацію найбільш екологічних проектів [2, с.52].

Для аграрних підприємств запровадження інновацій у виробництво - це передусім впровадження нових технологій виробництва сільськогосподарської продукції; застосовування нових, більш продуктивних порід у тваринництві та нових сортів рослин, більш продуктивних i стійкіших до захворювань та несприятливих до природно-кліматичних проявів; використання біотехнологій, які дають змогу отримати більш якісні, корисні продукти, що мають оздоровчий та профілактичний ефект; застосування нових технічних засобів та технологій обробітку грунту, очистки i зберігання сировини; застосування енергозберігаючих технологій, застосування екологічних інновацій, які відповідно дають змогу збільшити врожайність, продуктивність, мінімізувати витрати та гарантувати безпеку навколишнього середовища [5, с.51].

Інноваційні процеси в аграрному секторі мають свою специфіку. Вони відрізняються різноманіттям регіональних, галузевих, функціональних, технологічних і організаційних особливостей. Комплексний характер інновацій в аграрному секторі пред'являє специфічні вимоги до інноваційного механізму (нормативноправової бази інноваційного розвитку, організації i управлінню, інноваційному маркетингу, розвитку інноваційної структури тощо). Адже у 
сільському господарстві навіть щонайменше упущення повертається небажаними наслідками. Також, аграрні інновації порівняно з інноваціями в інших галузях економіки вирізняють: тривалий процес розробки новації, інновації носять, переважно, поліпшувальний характер, дослідження живих організмів, провідна роль науково-дослідних установ, залежність від природної зони та клімату. Це зумовлено, в першу чергу, особливостями самого сільського господарства, а саме, - основним фактором виробництва виступає земля, взаємодія 3 живими організмами (рослинами, тваринами, мікроорганізмами), сезонний характер виробництва, високий рівень ризику [3, с.75].

На думку Г.М. Саранчука, основними особливостями інноваційної діяльності в агропромисловому виробництві $є$ :

1) різноманітність сільськогосподарської продукції та продуктів ії переробки, вагома різниця в технологіях їх виробництва;

2) значна диференціація окремих регіонів країни за агротехнологічними умовами виробництва;

3) залежність використовуваних у сільському господарстві технологій від природних умов;

4) розпорошеність сільськогосподарського виробництва на значній території;

5) велика різниця в періодах виробництва окремих видів сільськогосподарської продукції;

6) відособленість сільськогосподарських товаровиробників від наукових установ, що займаються виробництвом науково-технічної продукції;

7) відсутність організаційно-економічного механізму передачі досягнень науки сільськогосподарським товаровиробникам [7].

Основною проблемою розвитку інноваційної діяльності $\epsilon$ нерозвиненість ринку інноваційної продукції, відсутність ефективного організаційно-економічного механізму управління інноваційними процесами. Науковотехнічні розробки не завжди $\epsilon$ продуктом, готовим для ефективної реалізації в агропромисловому виробництві. Відсутні структури, що займаються вивченням попиту на інновації. Для розвитку інноваційних процесів в сфері АПК необхідно вирішити ще цілу низку завдань державної інноваційної політики [3, с.75].

Існує чимало інших невирішених проблем ефективного використання інновацій та їх впровадження, що супроводжується втратою ним конкурентоспроможності не тільки на міжнародному, але й на місцевому рівнях. Головною причиною гальмування інноваційного розвитку $\epsilon$ брак фінансових ресурсів, спад платоспроможного попиту на вітчизняну продукцію з боку держави та підприємницького сектору, непривабливість вітчизняних підприємств для іноземних інвесторів через невміння держави фінансово грамотно спрямувати грошові потоки, негативний вплив інфляційних процесів, високі відсоткові ставки за банківські кредити, неплатоспроможність замовників, економічний ризик, недосконала нормативно-правова база регулювання інноваційної діяльності, яка $є$ фрагментарною, нецілісною і суперечливою та інші економічні та політико-правові проблеми [5, с.51].

Одним із найважливіших елементів діяльності аграрних підприємств має бути розроблення його інноваційної політики, яка міститиме у собі важливі стратегічні й тактичні аспекти. Метою інноваційної політики повинно бути запровадження інновацій у діяльність підприємств для забезпечення оптимального завантаження виробництва. Вона повинна відбуватися у двох напрямах:

1) акцент на потребах ринку і споживачів, яким відповідає маркетингова політика підприємства;

2) концентрація на ресурсах, тобто досягнення в науковій і виробничій сферах, технологіях, управлінських механізмах, оптимізуючи цим самим використання матеріальних, трудових, фінансових та інформаційних ресурсів суб'єкта господарювання [5, ст.52].

Для активізації інноваційної діяльності також важливим є створення інноваційних програм, які включать в себе узгодження організаційних питань, створення та впровадження інноваційних продуктів. На сьогоднішній день в аграрному секторі набуває поширення інноваційна стратегія довгострокового розвитку на засадах зрівноваженого розвитку (більш відома як стійкий розвиток (Sustainable development), яка $\epsilon$ загальною концепцією щодо необхідності встановлення балансу між задоволенням сучасних потреб і захистом інтересів майбутніх поколінь, включаючи їх потребу в безпечному i здоровому довкіллі. Ця концепція зумовлена виникненням нового виду інновацій екоінновації. До них належить виробництво екологічно чистої продукції, використання "дружніх" до довкілля технологій, ресурсозберігаючих технологій виробництва, концепція управління "зелений офіс", концепція "екоефективності", модель "чисте виробництво", методи підвищення ресурсної продуктивності на основі концепції MIPS, новий системний екологічний дизайн i спеціальне маркування продукції, що забезпечують високий рівень екологічної безпеки виробництва, продукції та послуг при одночасному зміцненні конкурентних позицій бізнесу [6].

Застосування екоінновацій дасть змогу не 
лише поліпшити екологічну ситуацію, а $є$ й забезпечити ефективність агропромислового виробництва, впроваджуючи інноваційні технології, зберігаючи робочі місця, покращуючи рівень життя; сприятиме формуванню стійких мережевих структур 3 підтримки й просування передового досвіду в галузі екоефективності.

Висновки i перспективи подальших досліджень. Стимулювання інноваційної діяльності у агропромисловому виробництві сприятиме підвищенню рівня життя, задоволенню потреб в продукції високої якості, створенні умови для регулярного відтворення виробництва i задоволеності населення. Це $€$ однією 3 головних передумов стабільності та сталого розвитку аграрного сектору економіки, оскільки дозволяє не лише змінити характер виробничої діяльності, але і наповнити ії новим значенням і практичним змістом. За таких умов господарюючі суб'єкти повинні обирати розвиваючу ринкову стратегію функціонування, яка стає визначальним чинником досягнення економічного лідерства, важливим інструментом у конкурентній боротьбі.

\section{ПЕРЕЛІК ВИКОРИСТАНИХ ДЖЕРЕЛ}

1. Офіційний сайт Міністерства аграрної політики та продовольства [Електронний ресурс]. - Режим доступу: http://minagro.gov.ua

2. Гончаренко О. В. Інституціональні аспекти реалізації інноваційних пріоритетів розвитку агропромислового виробництва [Електронний ресурс] / О. В. Гончаренко // Економіка. Управління. Інновації. Серія: Економічні науки. - 2016. - №1. - Режим доступу: http://nbuv.gov.ua/UJRN/eui_2016_1_5.

3. Готра В. В. Еволюція наукових поглядів на сутність поняття «інновація» та їі особливості в агропромисловому комплексі /Науковий вісник Ужгородського університету. Сер.: Економіка. - 2014. - №3. - С. 73-75.

4. Павлова Г.С. Інноваційний розвиток аграрного сектора національної економіки: теоретичні засади, методологія, механізми управління. Монографія.- Київ: ТОВ ДКС Центр, 2015. - 354 с.

5. Полегенька М.А. Особливості інноваційної діяльності в агропромислових підприємствах України / М. А. Полегенька // Агросвіт. - 2017. - № 6. - С. 49-54.

6. Рибіна Л.О. Екологічні аспекти інноваційного розвитку АПК / Л.О.Рибіна // Вісник Сумського національного аграрного університету. - 2009. -№ 2. - С. 78-83.

7. Саранчук Г.М. Інноваційний розвиток сільського господарства як основа підвищення його конкурентоспроможності / Г.М. Саранчук // Інноваційна економіка. - 2010. - № 1. - С.26-32.

\section{REFERENCES}

1. Ofitsiinyi sait Ministerstva agrarnoyi polityky ta prodovolstva [Official site of the Ministry of Agrarian Policy and Food of Ukraine [Electronic resource]. - Mode of access: http://minagro.gov.ua [in Ukrainian].

2. Honcharenko O.V. (2016), - Instytucionaljni aspekty realizaciji innovacijnykh priorytetiv rozvytku aghropromyslovogho vyrobnyctva, Ekonomika.Upravlinnya.Innovatsii, vol. 1.- Mode of access: http://nbuv.gov.ua/UJRN/eui_2016_1_5 [in Ukrainian].

3. Hotra V.V. (2014), - Evoljucija naukovykh poghljadiv na sutnistj ponjattja «innovacija» ta jiji osoblyvosti $\mathrm{v}$ aghropromyslovomu kompleksi, Naukovyj visnyk Uzhghorodsjkogho universytetu. Ser.: Ekonomika, vol.3, pp.73-75.

4. Pavlova Gh.Je. (2015) Innovacijnyj rozvytok aghrarnogho sektora nacionaljnoji ekonomiky: teoretychni zasady, metodologhija, mekhanizmy upravlinnja, Monoghrafija, $354 \mathrm{p}$.

5. Poleghenjka M.A. (2017) Osoblyvosti innovacijnoji dijaljnosti v aghropromyslovykh pidpryjemstvakh Ukrajiny, Aghrosvit, vol. 6, pp. 49-54.

6. Rybina L.O. (2009) Ekologhichni aspekty innovacijnogho rozvytku APK, Visnyk Sumsjkogho nacionaljnogho aghrarnogho universytetu, vol. 2, pp.78-83.

7. Saranchuk Gh.M. (2010) Innovacijnyj rozvytok siljsjkogho ghospodarstva jak osnova pidvyshhennja jogho konkurentospromozhnosti, Innovacijna ekonomika, vol.1, pp. 26-32.

Одержано12.09.2018 p. 